\title{
THE NEEM [AZADIRACHTA INDICA A. JUSS (MELIACEAE)] OIL REDUCTION IN THE IN VITRO PRODUCTION OF ZEARALENONE BY FUSARIUM GRAMINEARUM
}

\author{
Márcia Regina Ferreira Geraldo ${ }^{1}$; Christiane Luciana da Costa ${ }^{2}$; Carla Cristina Arrotéia ${ }^{3}$; Carlos Kemmelmeier $^{3 *}$ \\ ${ }^{1}$ Universidade Tecnológica Federal do Paraná, Campo Mourão, PR, Brasil; ${ }^{2}$ Universidade Estadual do Norte do Paraná, \\ Bandeirantes, PR, Brasil; ${ }^{3}$ Departamento de Bioquímica, Universidade Estadual de Maringá, Maringá, PR, Brasil.
}

Submitted: February 05, 2010; Approved: November 04, 2010.

\begin{abstract}
Zearalenone, a mycotoxin produced by fungi of the genus Fusarium, including F. graminearum, triggers reproduction disorders in certain animals and hyperestrogen syndromes in humans. Current research investigates three concentrations of neem oil extract $(0.1,0.25$ and $0.5 \%)$ in reducing the production of zearalenone. Neem oil extract decreased zearalenone amount in the three concentrations but highest inhibition $(59.05 \%)$ occurred at $0.1 \%$.
\end{abstract}

Key words: Zearalenone, Fusarium graminearum, neem oil extract.

Zearalenone (ZEA) is a non-steroid estrogen mycotoxin produced, by several fungi of the genus Fusarium, including $F$. graminearum, mainly in countries with a temperate and humid climate (18). The fungus causes reproduction disorders in animals (mainly in pigs) and hyperestrogen syndromes in humans. ZEA has also revealed to be hepatotoxic, hematotoxic, immunotoxic and genotoxic (22). F. graminearum Schwabe [sexual state: Gibberella zeae (Schwein.) Petch] infects cereals and causes several undesirable effects, including mycotoxins production in food with toxic potential in animals and human beings $(6,7,8,18)$. Synthetic chemical have been employed to control fungi in grains (4). However, the compounds revealed fungus resistance problems, besides the emergence of secondary pests (3). Plant natural extracts may be an alternative to substitute the synthetic chemical agents. Vegetal oils have been used as inhibitors of toxicogenic fungi and may be safer for consumption. In fact, an increasing demand for mycotoxin- free food and commodities may be perceived $(2,19)$. Extracts from neem (Azadirachta indica A. Juss), employed in pest control in plant cultures, $(15,20)$ reveal bioactive substances in all parts of the tree, especially in its seeds (12). It has been shown that neem seeds oil has fungitoxic effects (10), whereas in vitro investigations revealed the inhibitory effects of neem extracts in the production of several mycotoxins $(1,5,13,14)$. Owing to the toxic effects and financial losses caused by ZEA and to the fungitoxic potential of neem extract, current research verifies, through the in vitro method, whether neem oil extract reduces ZEA production by $F$. graminearum. ZEA was produced by the isolate of $F$. graminearum UEL 2118, producer of ZEA, and other mycotoxins (21), stored in Potato Dextrose Agar (PDA) in the fungus collection at the Laboratory of Chemistry and Physiology of Microorganisms of the Biochemistry Department of the State University of Maringá, Maringá PR Brazil. The isolate was first grown in a

\footnotetext{
*Corresponding Author. Mailing address: Department of Biochemistry, Universidade Estadual de Maringá. Avenida Colombo, 5790; 87020-900. Maringá. PR Brazil..; Tel.: +00 5544 3263-3655.; E-mail: ckemmelmeier@uem.br
} 
potato dextrose broth, at $25^{\circ} \mathrm{C}$, during seven days, and then cultivated in a rice medium to produce ZEA. Neem oil extract (NO) came from the commercial product BioNeem ${ }^{\circledR}$ produced from neem seeds. The method for the production, extraction and analysis followed Richardson et al (16). Medium for ZEA production was prepared by adding $5 \mathrm{~g}$ of rice to $3 \mathrm{ml}$ of deionized water in $100 \mathrm{ml}$ Erlenmeyer flasks, or rather, the control medium for the production of ZEA. Media for tests were prepared likewise, albeit with the addition of NO (BioNeem®). Media with final extract concentrations $0.1,0.25$ and $0.5 \%$ were obtained and were autoclaved at $121^{\circ} \mathrm{C}$ for 21 minutes in two consecutive days. After pre-culture of isolate 2118 in PDA broth at $25^{\circ} \mathrm{C}$ for seven days, it was ground in a homogenizer during 30 seconds. Further, $500 \mu \mathrm{l}$ of the culture were inoculated with a micropipette in rice media: control (without NO) and tests (with 0.1, 0.25 and $0.5 \%$ NO). They were incubated for 28 days at $25^{\circ} \mathrm{C}$ for the production of ZEA. For extraction, detection and quantification of ZEA, $10 \mathrm{ml}$ of ethyl acetate were added to cultures after incubation. Cultures were fragmented with a spatula, stirred and, after a 24-hour decantation, transferred to another flask and filtered with filter paper. Above procedure was repeated twice and then the two extracts were mixed. The extracts obtained were partitioned twice with $10 \mathrm{ml}$ hexane to remove interfering lipids. Final extract was concentrated in a rotary evaporator until completely dried. High Performance Liquid Chromatography (HPLC) to quantify ZEA was according Machado and
Kemmelmeier (9). Extracts for HPLC were concentrated and diluted in methanol (chromatographic degree) and previously filtered through a $0.45 \mu \mathrm{m}$ disposable syringe filter membrane (MFS-13 Micro Filtration Systems, California U.S.A) and analyzed $(20 \mu \mathrm{l})$ with a Shimadzu ${ }^{\circledR}$ liquid Chromatograph (Tokyo, Japan) equipped with a LC-10AD pump, a Rheodyne ${ }^{\circledR}$ injector, a SPD-10A UV detector, a CBM-101 Communications Bus Module and a Class-CR10 workstation system. A reversed-phase Shimpack ${ }^{\circledR}$ CLC-ODS (M0 column $(150 \times 4.6 \mathrm{~mm}, 5 \mu \mathrm{m})$ was used at $30^{\circ} \mathrm{C}$, with an equivalent pre-column $(10 \times 4.5 \mathrm{~mm})$. The mobile phase was methanol : water $(65: 35 \mathrm{v} / \mathrm{v})$ with $0.5 \mathrm{mM}$ of sodium hydroxide with a flow of $0.5 \mathrm{ml} /$ minute. Absorption was measured at $275 \mathrm{~nm}$. Data collection and integration were performed with ClassCR10 software (Shimadzu $^{\circledR}$, Tokyo, Japan). ZEA standard (Sigma®) $(100 \mu \mathrm{M})$ was used and amount of ZEA was calculated and expressed in $\mu \mathrm{g}$ of ZEA per gram of rice. All experiments were repeated four times and treatment results were statistically evaluated by two-way variance analysis (ANOVA), with $1 \%$ probability $(\mathrm{p}<0.01)$. When significant differences existed, means were analyzed by Tukey's test $(\mathrm{p} \leq 0.05)$, with statistical program SAS (SAS. Statistical Analysis System. Sas Institute Inc., Cary, NC, USA, 2001).

Results show that the production of ZEA in neem-less medium (control) was higher than that in extracts with NO (tests) (Figure 1 and Table 1).

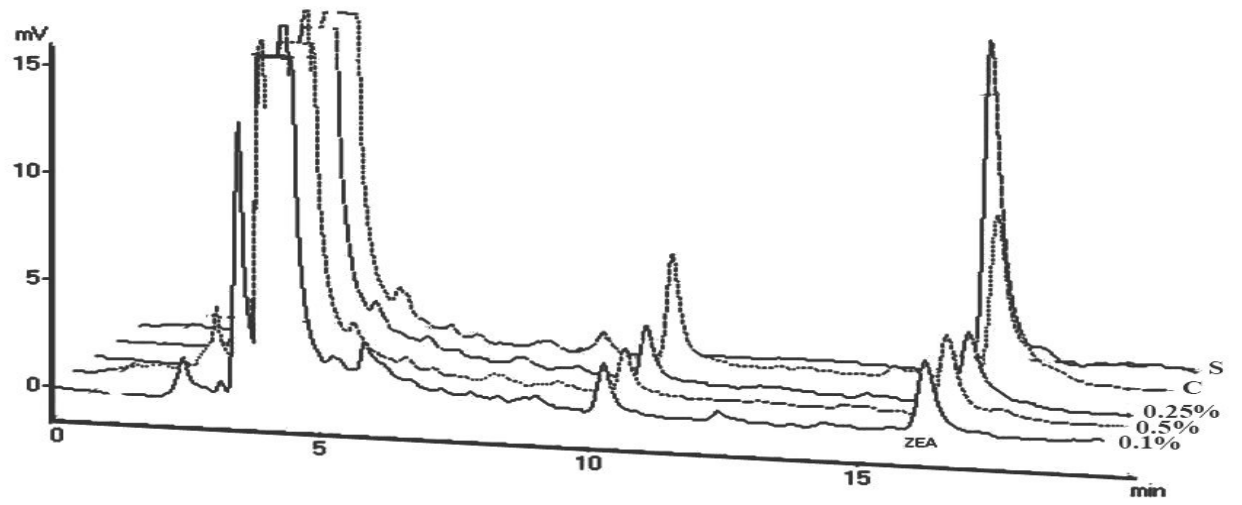

Figure 1. Profile of ZEA elution (HPLC) produced by $F$. graminearum: (S) ZEA standard; (C) control of ZEA production by $F$. graminearum grown in a medium without NO; $0.1,0.25$ and $0.5 \%$ production of ZEA by $F$. graminearum in media respectively with $0.1,0.25$ and $0.5 \%$ of NO. 
Table 1. Effect of neem oil extract $(\%)$ in the production of ZEA $(\mu \mathrm{g} / \mathrm{g})$ by $F$. graminearum (isolate UEL 2118).

\begin{tabular}{ccc}
\hline Treatments* $^{*}$ & Zearalenone $(\boldsymbol{\mu g} / \mathbf{g} \text { rice) })^{* *}$ & Decrease $(\%)$ \\
\hline Control $(0 \%$ neem $)$ & $0.240^{\mathrm{a}}( \pm 0.015)$ & - \\
$0.1 \%$ NO & $0.098^{\mathrm{c}}( \pm 0.007)$ & $59.05 \%$ \\
$0.25 \%$ NO & $0.152^{\mathrm{b}}( \pm 0.080)$ & $36.60 \%$ \\
$0.5 \%$ NO & $0.156^{\mathrm{b}}( \pm 0.026)$ & $34.74 \%$ \\
\hline
\end{tabular}

Details of assay were described above. Means followed by the same small letter in the column do not differ between themselves according to Tukey's test $(\mathrm{p}>0.05)$ * Control media without NO extract; media with NO extract **Values obtained by HPLC analysis, in $\mu \mathrm{g}$ of ZEA per $\mathrm{g}$ of rice. Rates between brackets: standard deviation.

Highest inhibition occurred at NO concentration $0.1 \%$, in which ZEA production decreased by $59.05 \%$ when compared to control. When NO concentration was increased from 0.25 to $0.5 \%$, inhibition of ZEA production was reduced by 36.60 and $34.74 \%$ respectively, when compared to control (Table 1). Most synthetic fungicides, which usually control fungi, produce several side effects, such as carcinogenicity, teratogenicity and residual toxicity (11). Studies with neem extracts have shown several inhibitory effects in toxigenic fungi, such as the blockage of the biosynthesis pathway of aflatoxin in Aspergillus parasiticus (23); decrease of citrinin in Penicillium citrinum (14); of penicillic acid in P. cycplopium (5); of patulin in P. expansum in vitro (13) and in contaminated apples (1). Current assay showed that concentrations 0.25 and $0.5 \%$ of NO inhibited less ZEA production than concentration $0.1 \%$. Since this fact is probably due to decrease of solubility of oil extract in water, lower concentrations may have had a higher contact with and absorption of the neem oil extract by the fungus. Similar results have been obtained in assays with patulin, in which NO in less than $0.5 \%$ concentrations highly decreased the production of patulin by $P$. expansum. This event shows that liposolubility is necessary for its activity (1). Current analysis showed that NO, popularly used worldwide for a great number of uses and ailments, may be an alternative medium for the partial control of ZEA production by $F$. graminearum. Nevertheless, further studies should be undertaken to verify ZEA inhibition in in vivo grains.

\section{REFERENCES}

1. Arroteia, C.C.; Kemmelmeier, C.; Machinski, M.Jr. (2007). Efeito dos extratos aquoso e oleoso de Nim [Azadirachta indica A. Juss (Meliaceae)] na produção de patulina em maçãs contaminadas por Penicillium expansum. Ciênc Rural, 37 1518-1523.

2. Bullerman, L.B. (1974) Inhibition of aflatoxin production by cinnamon. J Food Scien., 39, 1163-1165.

3. Cakir, A.; Kordali, S.; Kilic, H.; Kaya, E. (2005). Antifungal properties of essential oil and crude extract of Hypericum linarioides Bosse. Biochem Syst Ecol., 33, 245-256.

4. Chao, S.C.; Young, D.G.; Oberg, C.J. (2000). Screening for inhibitory activity of essential oils on selected bacteria fungi and viruses. $J$ Essent Oil Res., 12, 639-649.

5. Costa, C.L.; Kemmelmeier, C. (2008). Effect of aqueous and oily extracts from Neem [Azadirachta indica A. Juss (Meliaceae)] on the production of mycotoxins by the polyketide pathway (penicillic acid and sterigmatocystin). Cur Topics Biotechnol., 4, 35-40.

6. Dubin, H.J.; Gilchrist. L.; Reeves, L.; McNab, A. (1997). Fusarium Head Blight: Global status and Prospects, Proceedings of Workshop El Batan, Mexico CIMMYT, 13-17 October.

7. Geraldo, M.R.F.; Tessmann, D.J,; Kemmelmeier, C. (2006) Production of mycotoxins by Fusarium graminearum isolated from small cereals (wheat, triticale and barley) affected with scab disease in southern Brazil. Braz J Microbiol., 37, 58-63.

8. Kim, J C.; Kang, H.J.; Lee, D.H.; Lee, Y.W.; Yoshizawa, T. (1993) Natural occurrence of Fusarium mycotoxins (trichothecenes and zearalenone) in barley and corn in Korea. Appl Environ Microbiol., 59, 3798-3802.

9. Machado, L.C.H.; Kemmelmeier, C. (2000). Identification of deoxynivalenol, 3-acetyldeoxynivalenol and zearalenone in the galactose oxidase-producing fungus Dactylium dendroides. Mycopathologia, 149, $79-85$. 
10. Marques, R.P.; Monteiro, A.C.; Pereira, G.T. (2004). Crescimento, esporulação e viabilidade de fungos entomopatogênicos em meios contendo diferentes concentrações do óleo de Nim (Azadirachta indica). Ciênc Rural., 34, 1675-1680.

11. Mishra, A.K.; Dubey, N.K. (1994). Evaluation of some essential oils for their toxicity against fungi causing deterioration of stored food commodities, Appl Environ Microbiol., 60, 1101-1105.

12. Mossini, S.A.G.; Kemmelmeier, C. (2005). A árvore Nim (Azadirachta indica. A. Juss.): múltiplos usos. Acta Farmaceutica Bonaerense, 24, 139-148.

13. Mossini, S.A.G.; De Oliveira, K.P.; Kemmelmeier, C. (2004). Inhibition of patulin production by Penicillium expansum cultured with Neem (Azadirachta indica) Leaf Extracts. J. Basic Microbiol., 44, 106-113.

14. Mossini, S.A.G.; Kemmelmeier, C. (2008). Inhibition of citrinin production in Penicillium citrinum by Azadirachta indica A. Juss (Meliaceae) in culture. Int J Mol Sci., 9, 1676-1684.

15. Neves, B.P.; Oliveira, I.P.; Nogueira, J.C.M. (2003). Cultivo e utilização do nim indiano, Embrapa Circular Técnica, 62. Goiás.

16. Richardson, K.E.; Hagler, W.M. Jr.; Hamilton, P.B. (1984). Method for detecting production of zearalenone, zearalenol, T-2 toxin, and deoxynivalenol by Fusarium isolates. Appl Environ Microbiol., 47, 643646.
17. Sinhá, K.K.; Bhatnagar, D. (1998). Distribution of Fusarium species and their mycotoxins in cereal grains. in Mycotoxins in agriculture and food safety. Marcel Dekker, New York, USA, p.45-64.

18. Smith, J.E; Moss, M.O. (1985). Mycotoxins: Formation, analysis and Significance. John Wiley \& Sons, Great Britain.

19. Soliman, K.M.; Badeaa, R.I. (2002). Effect of oil extracted from some medicinal plants on different mycotoxigenic fungi. Food Chem Toxicol., 40, 1669-1675.

20. Suresh, G.; Narasimhan, N.S.; Masilamani, S.; Partho, P.D.; Gopalakrishnan, G. (1997). Antifungal fractions and compounds from uncrushed green leaves of Azadirachta indica. Phytoparasitica 25, 3339.

21. Wilbert, M.; Kemmelmeier, C. (2003). Identification of deoxynivalenol, 3-acetyldeoxynivalenol, and zearalenone in galactose oxidase-producing isolates of Fusarium graminearum. J Basic Microbiol., 43, 148-157.

22. Zinedine, A.; Soriano, J.M.; Moltó, J.C.; Manães, J. (2007). Review on the toxicity, occurrence, metabolism, detoxification, regulations and intake of zearalenone: An oestrogenic mycotoxin. Food Chem Toxicol., $45,1-18$.

23. Zeringue, H.J.Jr.; Batnagar, D. (1994). Effects of neem leaf volatiles on submerged cultures of aflatoxigenic Aspergillus parasiticus. Appl Environ Microbiol., 60, 3543-3547. 